\title{
ANALISIS HUKUM ISLAM TENTANG PELAKSANAAN SELAMATAN KEHAMILAN (PITONAN) DALAM RITUAL ADAT JAWA
}

\author{
Mujiyati \\ Universitas Nahdlatul Ulama Surakarta
}

\begin{abstract}
Abstrak
Tulisan ini bertujuan untuk mengetahui, pertama, apa alasan masyarakat di dukuh Pacingkerep Ngandul Sumberlawang Sragen menggunakan ritual selamatan kehamilan (pitonan); kedua, bagaimana prosesi selamatan kehamilan (pitonan) dalam adat jawa di dukuh Pacingkerep Ngandul Sumberlawang Sragen; dan ketiga, bagaimana menurut hukum Islam pelaksanaan selamatan kehamilan (pitonan) dalam adat jawa masyarakat di dukuh Pacingkerep Ngandul Sumberlawang Sragen. Penelitian ini menggunakan pendekatan sosiologis. Hasil penelitian menunjukkan alasan masyarakat di dukuh Pacingkerep Ngandul Sumberlawang Sragen menggunakan ritual selamatan kehamilan (pitonan) yaitu sebagai sarana untuk bersedekah, tasyakuran, dan selametan. Prosesi selamatan kehamilan (pitonan) dalam adat jawa di dukuh Pacingkerep Ngandul Sumberlawang Sragen ada beberapa tahapan. Hukum Islam pelaksanaan selamatan kehamilan (pitonan) dalam adat jawa masyarakat di dukuh Pacingkerep Ngandul Sumber lawang Sragen. Bahwa dalam tradisi selamatan kehamilan dapat saja dilakukan yang penting masyarakat tidak mengimani simbolsimbol yang terkait di dalam upacara selamatan kehamilan tersebut. Selamatan kehamilan juga merupakan perwujudan rasa syukur kepada Allah SWT sehingga dengan adanya tingkeban ini masyarakat melakukan salah satu perwujudan rasa syukurnya serta bersedekah kepada orang-orang.
\end{abstract}

Kata kunci: Selametan, Kehamilan, Hukum Islam 


\section{Abstract}

This paper aims to find out, first, what is the reason for the community in Pacingkerep Ngandul Sumberlawang Sragen using pregnancy survivor rituals (pitonan); second, how the procession of pregnancy survivors (pitonan) in Javanese customs in dukuh Pacingkerep Ngandul Sumberlawang Sragen; and third, how according to Islamic law the implementation of pregnancy survivors (pitonan) in Javanese customs in dukuh Pacingkerep Ngandul Sumberlawang Sragen. This research uses a sociological approach. The results showed the reason for the community in dukuh Pacingkerep Ngandul Sumberlawang Sragen using the ritual of pregnancy congratulations (python) to give alms, tasyakuran, and diving. There are several stages of the procession of pregnancy survivors (pitonan) in Javanese custom in dukuh Pacingkerep Ngandul Sumberlawang Sragen. Islamic law implements pregnancy survivors (pitonan) in Javanese customs communities in dukuh Pacingkerep Ngandul Sumber Lawang Sragen. The tradition of pregnancy survivors can be done, which is essential the community does not believe in the symbols associated with the ceremony of pregnancy congratulations. Pregnancy congratulations are also an embodiment of gratitude to Allah SWT so that with this tingkeban the community does one of the manifestations of gratitude and almsgiving to the people.

Keywords: Selametan, Pregnancy, Islamic Law

\section{A. PENDAhuluan}

Kehamilan adalah sebuah anugerah terbesar dari Allah SWT bagi pasangan baru suami istri dalam perjalanan rumah tangga. Kehamilan seorang istri adalah pertanda akan lahirnya anak keturunan yang menjadi buah kasih sayang. Kehadiran anak membangkitkan semangat orang tua untuk membangun rumah tangga bahagia, penuh cinta kasih dan sayang, menjadi tumpuhan harapan hidup di masa depan, dan kepadanya segala cita-cita digantungkan.

Sebagai ungkapan rasa syukur dalam menyambut berita gembira kehamilan dari pasangan suami istri, dalam masyarakat Jawa terdapat suatu tradisi berupa ritual yang khusus diperuntukkan bagi 
seorang wanita yang sedang mengandung, yaitu

"Selamatan ngapati (saat kandungan berusia empat bulan), dan slametan mitoni (pada saat usia kandungan genap enam atau tujuh bulan). Selamatan ini disebut dengan Tingkepan. Ada juga yang menyebut dengan "mrocoti”, yang merupakan bentuk tafa'ul, seraya mengharapkan agar janin dalam kandungan dan ibunya sehat, pada saat kelahiranya lancar, langsung keluar (procot, Jawa) tanpa ada kesulitan dan halangan apapun”.

Senada dengan hal tersebut, menurut Aswab Mahasin sebagaimana dikutip oleh Clifford Geertz mengatakan upacara tingkeban atau mitoni adalah "upacara selametan yang diselenggarakan pada bulan ketujuh masa kehamilan dan hanya dilakukan apabila anak yang dikandung adalah anak pertama bagi si ibu, si ayah atau keduanya". ${ }^{2}$ Upacara ini dimaksudkan untuk memohon keselamatan, baik bagi ibu yang mengandung maupun calon bayi yang akan dilahirkan. Pada umumnya masyarakat Jawa dalam menyelenggarakan tingkeban dilakukan serangkaian upacara di antaranya "Siraman, ganti pakaian, brojolan, dan Slametan".

Pelaksanaan mitoni selain terbentuk dari pola lama yaitu sebelum ajaran agama Islam masuk ke dalam Indonesia yang masih erat dengan kebudayaan Hindu yang berasal dari kerajan Kediri namun dilihat dari proses perkembangannya pelaksanaan tradisi ini semakin menunjukan nilai-nilai keIslamannya. Ajaran Islam yang terkandung di dalam tingkeban/ mitoni ini pada dasarnya yaitu selametan ataupun pengungkapan rasa syukur kepada Allah SWT sebagai pencipta dan pemberi rezeki dan karunia kepada manusia. Anak merupakan salah satu karunia yang diberikan oleh Allah sebagi penerus rezeki dan karunia kepada manusia. Anak merupakan salah satu karunia yang diberikan oleh Allah sebagai penerus keluarga ataupun keturunan, dengan demikian wanita yang sedang mengandung seorang anak, pada umur kandungannnya tujuh bulan mengadakan selametan atau syukuran.

Apabila kandungan sudah mulai berbobot ataupun sudah mempunyai beban yang dalam keadaan ini kemudian dikatakan tujuh bulan kehamilan

\footnotetext{
${ }^{1}$ Maia, Pengertian Mitoni, http://www.lacasacomics.com/2014/12/doa-walimatul-haml-ngapati4-bulan-dan.html, hal. 1. (Diakses pada tanggal 20 Desember 2015)

${ }^{2}$ Clifford Geertz, Abangan, Santri, Priyayi dalam Masyarakat Jawa, (Jakarta: Pustaka Jaya, 1983), hal. 48.

${ }^{3}$ Ibid., hal. 50
} 
seorang wanita. Waktu tersebut dipilih karena pada waktu tersebut janin yang ada di dalam perut ibu yang hamil sudah mempunyai bentuk yang sempurna dan hanya menunggu kelahirannya, sehingga pada umur tersebut pasangan suami istri diperintahkan untuk senantiasa bersyukur dan memohon agar diberikan anak yang sehat, normal dan utuh.

Sebagaimana yang telah dilakukan oleh masyarakat di Dukuh Pacingkerep Ngandul Sumberlawang Sragen, masih menggunakan upacara mitoni ketika penduduk yang usia kehamilannya mencapai tujuh bulan. Banyak serangkaian acara yang dilaksanakan ketika upacara tersebut. Rutinitas tersebut masih dilaksanakan masyarakat dari zaman dahulu sampai sekarang.

Ada banyak rangkaian upacara tradisional adat Jawa sejak ibu mulai hamil, sampai melahirkan anaknya. Desa mawa cara, negara mawa tata artinya setiap desa mempunyai cara sendiri-sendiri, setiap negara mempunyai aturan sendiri-sendiri. Ada variasi atau perbedaan dari berbagai upacara antar daerah. Umumnya, upacara ini dilakukan dalam bentuk selamatan, untuk memohon keselamatan pada Tuhan YME.

Selamatan adalah upacara sedekah makanan dan doa yang bertujuan untuk memohon keselamatan dan ketentraman untuk ahli keluarga yang menyelenggarakan. Upacara selamatan termasuk kegiatan batiniah yang bertujuan untuk mendapat ridha dari Tuhan. Kegiatan selamatan menjadi tradisi hampir seluruh pedusunan di Jawa. Bahkan ada yang menyakini bahwa selamatan merupakan syarat spiritual yang wajib dan jika dilanggar akan mendapatkan ketidak berkahan atau kecelakaan.

Upacara ini dilaksanakan pada usia kehamilan tujuh bulan dan pada kehamilan pertama kali. Upacara ini bermakna bahwa pendidikan bukan saja setelah dewasa akan tetapi semenjak benih tertanam di dalam rahim ibu. Dalam upacara ini sang ibu yang sedang hamil dimandikan dengan air kembang setaman dan disertai doa yang bertujuan untuk memohon kepada Allah agar selalu diberikan rahmat dan berkah sehingga bayi yang akan dilahirkan selamat dan sehat. Senada dengan hal tersebut menurut tradisi Jawa pelaksanakan upacara mitoni dilaksanakan:

Pada tanggal ganjil sebelum bulan purnama seperti 3, 5, 7, 9, 11, 13 atau 15. bulan Jawa, dilaksanakan di kiri atau kanan rumah menghadap 
kearah matahari terbit. Yang memandikan jumlahnya juga ganjil misalnya 5, 7, atau 9 orang. Setelah siram di pakaikan kain /jarik sampai tujuh kali, yang terakhir/ ketujuh yang dianggap paling pantas dikenakan, kemudian acara pemotongan tumpeng tujuh yang diawali dengan doa kemudian makan rujak.dst. Hakekat yang mendasar dari semua tradisi Jawa adalah suatu ungkapan syukur dan permohonan kepada Yang Maha Kuasa untuk keselamatan dan kenteraman, namun di ungkapkan dalam bentuk lambanglambang yang masing-masing mempunyai makna. ${ }^{4}$

Senada dengan hal tersebut, jauh-jauh hari sebelum usia kandungan memasuki tujuh bulan, calon orang tua bayi harus menentukan hari yang baik sesuai petungan Jawa. Menurut petungan Jawa hari-hari yang baik itu yang memiliki neptu genap dan jumlahnya 12 atau 16. Hari-hari yang baik adalah yang neptunya 12 atau 16 misal Kamis Kliwon, Senin Kliwon, Akhad Pon dan sebagainya. Kamis memiliki neptu 8 dan Kliwon memiliki neptu 8 jadi Kamis Kliwon memiliki neptu 16, begitu juga Senin Kliwon memiliki neptu 12 dan Ahad Pon memiliki neptu 12.

Selain penentuan hari yang ada aturannya, segala ubo rampe atau piranti juga sangat rumit pula. Masing-masing ritual ada piranti sendirisendiri yang beraneka ragam. Semua piranti tersebut disediakan bukan tanpa maksud. Upacara tersebut dimulai dengan acara kenduri telon-telon yang dihadiri oleh tetangga, kerabat, sanak saudara dan lain-lain. Semua piranti telon-telon dibawa ke hadapan undangan. Setelah semua piranti dihidangkan berjonggo atau sesepuh desa ngujubne yaitu menjelaskan maksud dan tujuan diadakannya upacara tersebut dan menjelaskan makna satu per satu dari makanan yang telah terhidang. Dengan sautan undangan dengan katakata nggeh disetiap akhir kalimat yang diucapkan oleh berjonggo. Satu per satu makanan yang dihidangkan dijelaskan hingga usai dan dilanjutkan dengan do'a, dan yang terakhir dari rangkaian acara pertama ini adalah memakan hidangan yang telah tersedia.

Ada beberapa ahli yang mengemukakan pendapatnya tentang pengertian kehamilan yaitu sebagai berikut:

Kushartanti sebagaimana dikutip Wulan mengatakan kehamilan adalah "di kandungnya janin dari hasil pembuahan sel

\footnotetext{
${ }^{4}$ Devania, Op.Cit., hal. 4.
} 
telur oleh sel sperma".s Hanifa sebagaimana dikutip Wulan mengatakan "masa kehamilan pada wanita hamil dimulai dan konsepsi sampai lahirnya janin, lamanya kehamilan normal 280 hari dihitung dari hari pertama haid terakhir" Guyton sebagaimana dikutip Wulan mengatakan kehamilan adalah "suatu rangkaian peristiwa yang baru terjadi bila ovum dibuahi dan pembuahan tersebut berkembang sampai menjadi fetus".?

Berdasarkan pendapat diatas dapat disimpulkan bahwa kehamilan merupakan suatu rangkaian peristiwa yang baru terjadi bila ovum dibuahi dan lamanya kehamilan normal 280 hari dihitung dari hari pertama haid terakhir.

Saat hamil seorang wanita akan banyak mengalami perubahan pada kondisi fisik tubuhnya, perubahan tersebut mungkin relatif pada tiap-tiap wanita. Saat hamil merupakan saat-saat paling membahagiakan bagi seorang calon ibu dan juga merupakan saat-saat perjuangan karena ia harus membawa beban berat selama sembilan bulan kemana pun ia pergi yaitu calon buah hatinya.

Proses terjadinya kehamilan sendiri terjadi saat sel sperma laki-laki bertemu dengan sel telur matang dari wanita bertemu (kemudian terjadi proses pembuahan). Pertemuan itu terjadi setelah melakukan hubungan suami istri dan akan bisa berhasil jika di lakukan oleh perempuan dewasa pada masa suburnya.

Sejatinya pendidikan agama memang sudah seharusnya kita berikan semenjak anak masih dalam kandungan. Banyak pula cara menurut Islam dalam hal memberikan pendidikan semenjak dalam kandungan sampai anak nantinya mencapai usia dewasa. Dasar pemahaman agama yang baik akan banyak berpengaruh dalam hal pembentukan karakter dan akhlak seorang anak nantinya.

Mendidik anak secara Islami semenjak dalam kandungan seorang ibu penting untuk diketahui oleh setiap orang tua. Orang tua tentunya tidak menginginkan anak-anaknya menjadi anak yang durhaka. Semoga kita

5 Wulan, Pengertian Kehamilan, http://www.kopi-ireng.com/2015/01/definisi-dan-pengertiankehamilan.html, hal. 1. (Diakses pada tanggal 30 Juli 2016)

${ }^{6}$ Ibid., hal. 2.

${ }^{7}$ Ibid., hal. 2. 
terhindar dari hal sedemikian, karena setiap orang tua menginginkan anakanaknya menjadi anak kebanggaan dan senantiasa menjadi salah seorang yang senantiasa menjaga agama Islam ini untuk tetap bercahaya sampai akhir jaman nantinya.

Selain itu, sebagai seorang muslim, orang tua juga memiliki kewajiban untuk mendidik tentang ajaran Islam terhadap anaknya. Anak adalah amanat yang harus dijaga dan ditanamkan kepadanya nilai-nilai tauhid dan akhlak yang baik, dengan tujuan agar menjadi hamba Allah yang taat dan patuh terhadap-Nya. Jika ajaran-ajaran Islam ini tidak diperoleh anak di masa hidupnya di dunia, maka kelak di kehidupan akhirat, anaklah yang akan menjadi penuntut pertama dan menjadi alasan serta penyebab terhalangnya orang tua masuk surga.

Hanya saja seringkali pendidikan agama sering terlupakan padahal pendidikan agama adalah pondasi paling penting dalam mendidik anak. Selain dari pendidikan agama contoh serta tauladan yang baik dari orang tua serta lingkungan yang baik adalah hal yang tidak boleh dilupakan untuk bisa mendidik dan mengarahkan anak-anak kita mengenal akan.

\section{B. METODE PENELITIAN}

Dalam penelitian ini penulis menggunakan pendekatan sosiologis. Pendekatan sosiologis ini penulis gunakan untuk mengetahui bagaimana prosesi dan ritual selamatan kehamilan (pitonan) dalam adat jawa masyarakat di dukuh Pacingkerep Ngandul Sumberlawang Sragen. Sedangkan dalam penelitian ini jenis penelitian yang digunakan yaitu penelitian field research (penelitian lapangan). Penelitian ini dilakukan di Dukuh Pacingkerep Ngandul Sumber lawang Sragen. Peneliti memilih lokasi ini sebagai tempat penelitian karena di Dukuh Pacingkerep mayoritas penduduknya beragama Islam bahkan dapat dikatakan hampir $100 \%$ penduduknya beragama Islam. Namun di dukuh tersebut masih banyak masyarakat yang masih menggunakkan ritual adat jawa dalam acara selamatan misalnya selamatan kehamilan (pitonan). Sehingga dalam hal ini menjadi menarik untuk diteliti dukuh yang notabenenya mayoritas beragama Islam namun penduduknya ternyata masih percaya dengan halhal yang berbau magis dan tradisi kejawen. Dalam analisis ini penulis 
menggunakan analisis deskriptif yang mendiskripsikan tentang tinjauan dalam Fiqih yang bersumber dari Al-Qur'an dan Al-Hadist maupun fatwafatwa tentang ritual selamatan kehamilan (pitonan) yang dilakukan oleh masyarakat Islam di dukuh Ngandul Pacingkerep Sumberlawang Sragen. Untuk menetapkan keabsahan data penelitian ini adalah dengan menggunakan derajat kepercayaan (Credibility).

\section{HASIL DAN PEMBAHASAN}

\section{Analisis Alasan Masyarakat di Dukuh Pacingkerep Ngandul Sumberlawang Sragen}

Setelah peneliti mengadakan wawancara dengan Bapak Sugino selaku Ketua RT, Ibu Samikem selaku Dukun Pitonan dan Bapak Margini selaku tokoh masyarakat pada tanggal 25 Juni- 25 Juli 2016 dalam penelitian tentang tradisi pelaksanaan selamatan kehamilan (pitonan) dalam adat Jawa, memberikan beberapa penafsiran, pemahaman dan pandangan yang berbeda-beda. Hal ini dikarenakan masyarakat di Dukuh Pacingkerep Ngandul SumberLawang Sragen termasuk masyarakat yang plural dan kompleks. Sehingga masing-masing golongan atau kalangan memiliki pemahaman yang berbeda-beda dan beragam terhadap tradisi pelaksanaan selamatan kehamilan (pitonan) tersebut. Dari alasan yang disampaikan oleh berbagai golongan atau kalangan antara lain:

a. Golongan agama

Para santri serta tokoh agama menganggap bahwa diadakan tradisi selamatan kehamilan (pitonan) adalah sebagai sarana untuk bersedekah, tasyakuran, dan selametan. Dikatakan sedekah karena shohibul hajat mengeluarkan hartanya yang berupa hidanganhidangan untuk para tamu undangan acara tersebut, dikatakan tasyakuran karena merupakan bentuk rasa syukur shahibul hajat atas karunia yang telah diberikan oleh Allah SWT yang berupa titipan sang jabang bayi. Dikatakan selamatan karena dengan bersedekah merupakan tasyakuran cara untuk memohon keselamatan ibu dan sang jabang bayi agar diberi kemudahan pada saat mengandung sampai melahirkan. 
b. Masyarakat

Pengumuman akan usia kandungan, sehingga masyarakat sekitar mengetahui bahwa usia kandungan ibu shohibul hajat, dan mengumumkan berita gembira bahwa shohibul hajat akan mempunyai bayi. Serta menghormati tradisi, karena menghadiri undangan dalam pelaksanaan tradisi selamatan kehamilan (pitonan) berarti ikut melestarikan tradisi masyarakat Jawa khususnya masyarakat di Dukuh Pacingkerep Ngandul Sumberlawang Sragen. Hal tersebut untuk memohon keselamatan untuk calon bayi dan ibu. tujuan pengharapan doa restu dari para warga agar calon bayi kelak lahir dengan selamat dan menjadi anak yang soleh atau sholehah serta calon ibu selamat. Dalam pelaksanaan tradisi selamatan kehamilan di Dukuh Pacingkerep Ngandul Sumberlawang Sragen menggunakan pembacaan surat al-Fatihah pembacaan doa berdasarkan kajian peneliti mempunyai fadhilah tersendiri yang akan diuraikan dibawah ini. Pembacaan doa yang merupakan sari pati penghambaaan diri kepada Allah.

\section{Analisis Prosesi Selamatan Kehamilan (pitonan) Dalam Adat Jawa di Dukuh Pacingkerep Ngandul Sumberlawang Sragen}

Upacara tingkeban adalah salah satu tradisi masyarakat Jawa, upacara ini disebut juga mitoni berasal dari kata pitu yang arti nya tujuh, upacara ini dilaksanakan pada usia kehamilan tujuh bulan dan pada kehamilan pertama kali. Upacara ini bermakna bahwa pendidikan bukan saja setelah dewasa akan tetapi semenjak benih tertanam di dalam rahim ibu. Adapun prosesi selamatan kehamilan dalam adat Jawa di Dukuh Pacingkerep Ngandul Sumberlawang Sragen yaitu:

a. Siraman yang di lakukan oleh para sesepuh sebanyak 7 orang termasuk ayah dan ibu wanita hamil serta suami dari calon ibu. Siraman ini bermakna memohon doa restu agar proses persalinan lancar dan anak yang akan dilahirkan selamat dan sehat jasmani dan rohani. Sebaiknya yang memandikan adalah orang tua yang sudah mempunyai cucu.

b. Setelah siraman selesai, dilanjutkan dengan upacara memasukan telur ayam dan cengkir gading. Calon ayah memasukan telur ayam mentah 
ke dalam sarung/kain yang di kenakan oleh calon ibu melalui perut sampai pecah kemudian menyusul kedua cengkir gading di teroboskan dari atas ke dalam kain yang di pakai calon ibu sambil di terima di bawah oleh calon nenek dan kelapa gading tersebut di gendong oleh calon nenek dan di letak kan sementara di kamar. Hal ini merupakan simbol harapan semoga bayi akan lahir dengan mudah tanpa ada halangan.

c. Upacara ganti pakaian, calon Ibu mengenakan kain putih sebagai dasar pakaian pertama, kain tersebut melambangkan bahwa bayi yang akan di lahirkan adalah suci dan mendapat berkah dari Tuhan. Calon Ibu berganti baju 6 kali dengan di iringi pertanyaan "sudah pantas belum?", dan dijawab oleh ibu-ibu yang hadir "belum pantas" sampai yang terakhir ke tujuh kali dijawab "pantas". Sebagai informasi, kain yang dipakai pada upacara berganti busana memiliki beberapa pilihan motif yang semuanya dapat dimaknai secara baik yaitu sebagai berikut:

1) Wahyu Temurun

Maknanya agar bayi yang akan lahir menjadi orang yang selalu mendekatkan diri pada Allah SWT dan selalu mendapat perlindungan Nya.

2) Sido Asih

Maknanya agar bayi yang akan lahir akan selalu mendapatkan cinta dan kasih oleh sesama dan memiliki sifat belas kasih.

3) Sido Mukti

Maknanya agar bayi yang akan lahir memiliki sifat berwibawa dan disegani oleh sekelilingnya.

4) Truntum

Maknanya agar keluhuran budi kedua orang tua menurun pada sang bayi.

5) Sido Luhur

Maknanya agar bayi yang akan lahir akan memiliki sifat berbudi pekerti luhur dan sopan santun 
6) Semen Romo

Maknanya agar bayi yang dilahirkan memiliki rasa cinta kasih kepada sesama layaknya cinta kasih Rama dan Sinta kepada rakyatnya.

7) Sido Dadi

Maknanya agar bayi yang di lahirkan kelak akan selalu sukses dalam hidupnya

8) Babon Anggrem

Maknanya berisi harapan agar calon ibu dapat melahirkan secara normal dan lancar.

d. Setelah selesai mengenakan kain dan kebaya sebanyak 7 kali, dilaksanakan pemutusan benang lawe atau janur yang dilingkarkan di perut calon ibu, dilakukan oleh calon ayah dengan maksud agar bayi yang dikandung akan lahir dengan mudah.

e. Setelah upacara ganti busana calon ibu duduk di atas tumpukan baju dan kain yang tadi habis digunakan. Hal ini memiliki simbol bahwa calon ibu akan selalu menjaga kehamilan dan anak yang di kandungnya dengan hati hati dan penuh kasih sayang. Calon Ayah menyuapi calon Ibu dengan nasi tumpeng dan bubur merah putih sebagai symbol kasih sayang seorang suami dan calon ayah.

f. Upacara mecah kelapa, kelapa gading yang tadi dibawa ke kamar, kembali di gendong oleh calon nenek untuk dibawa keluar dan diletakkan dalam posisi terbalik (gambar tidak terlihat) untuk dipecah, Kelapa gadingnya berjumlah 2 dan masing-masing di gambari tokoh Wayang Kamajaya dan Kamaratih. Calon ayah memilih salah satu dari kedua kelapa tersebut. Apabila calon ayah memilih Kamajaya maka bayi akan lahir laki laki, sedangkan jika memilih Kamaratih akan lahir perempuan (hal ini hanya pengharapan saja, belum merupakan suatu kesungguhan)

g. Dodol rujak, pada upacara ini, calon ibu membuat rujak didampingi oleh calon ayah, para tamu yang hadir membelinya dengan menggunakan kereweng sebagai mata uang. Makna dari upacara ini 
agar kelak anak yang di lahirkan mendapat banyak rejeki dan dapat menghidupi keluarganya.

Dalam pelaksanaan tradisi tingkeban di Dukuh Pacingkerep Ngandul Sumberlawang Sragen pembacaan surat al-fatihah. Pembacaan Al-fatikhah berdasarkan kajian peneliti mempunyai fadhilah yaitu pembacaan Al-fatikhah yang merupakan sari pati penghambaaan diri kepada Allah. Sebagaimana firman Allah dalam Al-Qur'an surat AlMu'min ayat 60.

Sedangkan membaca Al-Qur'an adalah salah satu rangkain amalamal pokok dalam agama Islam, sebagaimana shalat dan infak. Karena pentingnya membaca Al-Qur'an, Rasulullah memerintahkan agar setiap keluarga mendidik putra-putrinya membaca Al-Qur'an. Dari uraian di atas, maka dengan membaca surat Al-Fatihah yang merupakan ayat-ayat Al-Qur'an dalam tradisi selamatan kehamilan, shahibul hajat mempunyai harapan agar diberi keberkahan, dan karunia dari Allah SWT dan dengan pembacaan surat-surat tersebut maka secara tidak langsung juga telah mendidik si jabang bayi untuk membaca Al-Qur'an. Hal ini dikarenakan si jabang bayi saat pelaksanaan tradisi selamatan kehamilan mendengarkan apa yang dibaca ketika pelaksanaan tradisi selamatan kehamilan berlangsung. Pembacaan surat Al-Fatihah dimaksudkan untuk melandasi terkabulnya doa. Dengan demikian khasiat pembacaan surat Al-Fatihah tersebut juga berkaitan dengan penyataan niat agar mudah terkabulnya maksud.

\section{Analisis Hukum Pelaksanaan Selamatan Kehamilan (pitonan) dalam}

\section{Adat Jawa Masyarakat di Dukuh Pacingkerep Ngandul Sumberlawang Sragen}

Sekarang masyarakat Islam masih banyak orang yang melaksanakan tingkeban atau mitoni, dengan tatacara yang sedikit berbeda (atau dibedakan) dengan tradisi Jawa. Keluarga yang memiliki ibu yang hamil tujuh bulan mengajak tetangga-tetangganya guna dimintai pertolongan untuk membacakan beberapa surat tertentu dari Al-Quran, seperti surat Al- fatihah. Mereka membaca bersama-sama dengan bagian yang berbeda-beda, surat yang panjang biasanya dibagi dua atau tiga orang, sehingga dalam waktu kurang lebih setengah jam bacaan AlQuran sudah selesai dan diakhiri dengan pembacaan doa oleh imamnya. 
Selamatan kehamilan, seperti 3 bulanan atau 7 bulanan (Nujuh Bulanan), tidak ada dalam ajaran Islam. Itu termasuk perkara baru dalam agama. Dan semua perkara baru dalam agama adalah bid'ah. Kemudian, jika selamatan kehamilan tersebut disertai dengan keyakinan akan membawa keselamatan dan kebaikan, dan sebaliknya jika tidak dilakukan akan menyebabkan bencana atau keburukan, maka keyakinan seperti itu merupakan kemusyrikan. Karena sesungguhnya keselamatan dan bencana itu hanya di tangan Allah sebagaimana firman Allah dalam Al-Qur'an surat Al Maidah ayat 76.

Ditinjau dari aspek agama, fenomena ini berhadapan dengan dua versi. Yang pertama, fenomena ini (tradisi ritual) bisa dilestarikan dalam kehidupan masyarakat di Dukuh Pacingkerep, namun harus dilakukan beberapa perubahan yang tampak dalam prosesi tradisi ritual ini, karena dalam prosesinya terdapat unsur mubazdir. pertama, seperti penjatuhan telur secara sia-sia. Kedua, prosesi dalam tradisi ritual ini mutlak ditinggalkan, karena ada semacam pembahauran antara budaya Islam yang memang sengaja disisipkan dan budaya non Islam yang agak komplein yang hal ini pada akhirnya tradisi semacam ini akan menggiring kepada faham Dualisme yaitu Monoteisme dan Animisme atau Dinamisme. Sementara ini, Islam mengajarkan kemurnian dalam berbagai segi termasuk dalam manifestasi ajaran-ajaran Islam, karena Islam mempunyai komitmen (qa'idah).

Melihat prosesi dan keyakinan diatas, para ulama memberi perhatian serius terhadap masalah ini. Bila selamatan kehamilan itu diyakini dan atau dikaitkan dengan agama, sehingga menyebabkan ketakutan jika tidak melaksanakannya, maka hal ini jelas menyimpang dari syariat Islam. Karena Allah tidak mensyariatkan hal tersebut sehingga akan mengarah pada upaya menambahi agama dan tergolong bid'ah yang sesat. Akan tetapi, jika acara ini tidak diyakini sebagai bagian dari ibadah maka para ulama mempunyai pendapat yang berbeda. Sebagian ulama melarang jenis ritual seperti ini, karena tidak ada syariat yang mendasarinya. Tujuannya tak lain untuk membendung rusaknya agama dari munculnya bid'ah yang jelas-jelas dilarang agama. Karena bagaimanapun, Islam telah disempurnakan bagi umat manusia sebagai jalan yang lurus menuju ridho Allah Ta'ala. 
Dari situ dapat diambil kesimpulan, bahwa harapan yang terkandung dalam prosesi selamatan kehamilan mampu dicapai dengan ibadah yang telah ditetapkan dalam syariat. Jika dilihat lebih dalam, pelaksanaan tingkeban ini syarat dengan keyakinan-keyakinan yang mengarah pada terbentuknya penyandaran diri selain kepada Allah. Ini dapat dilihat dari penentuan hari dalam pelaksanaannya, proses siraman untuk menghilangkan kejahatan hingga simbol pemecahan telur, Keyakinan-keyakinan ini jelas tidak berdasar, sehingga mampu menyeret pelakunya pada lembah syirik yang jelas-jelas dibenci oleh Allah. Perbuatan syirik merupakan perbuatan yang sangat halus, maksudnya ketika manusia tidak berhati-hati dalam segala perbuatan, maka ia tergelincir di dalamnya, dan itu akan menimbulkan bahaya bagi pelakunya.

\section{KESIMPULAN}

Alasan masyarakat di dukuh Pacingkerep Ngandul Sumberlawang Sragen menggunakan ritual selamatan kehamilan (pitonan) yaitu sebagai sarana untuk bersedekah, tasyakuran, dan selametan. Dikatakan sedekah karena shohibul hajat mengeluarkan hartanya yang berupa hidanganhidangan untuk para tamu undangan acara tersebut, dikatakan tasyakuran karena merupakan bentuk rasa syukur shahibul hajat atas karunia yang telah diberikan oleh Allah SWT yang berupa titipan sang jabang bayi, dan menghormati tradisi, karena menghadiri undangan dalam pelaksanaan tradisi selamatan kehamilan (pitonan) berarti ikut melestarikan tradisi masyarakat Jawa khususnya masyarakat di Dukuh Pacingkerep Ngandul Sumberlawang Sragen. Hal tersebut untuk memohon keselamatan untuk calon bayi dan ibu. tujuan pengharapan doa restu dari para warga agar calon bayi kelak lahir dengan selamat dan menjadi anak yang soleh atau sholehah serta calon ibu selamat.

Prosesi selamatan kehamilan (pitonan) dalam adat jawa di dukuh Pacingkerep Ngandul Sumberlawang Sragen ada beberapa tahapan dalam prosesi tersebut yaitu siraman yang dilakukan oleh para sesepuh sebanyak 7 orang termasuk ayah dan ibu wanita hamil serta suami dari calon ibu, upacara memasukan telur ayam dan cengkir gading, upacara ganti pakaian, calon Ibu mengenakan kain putih sebagai dasar pakaian pertama, kain 
tersebut melambangkan bahwa bayi yang akan dilahirkan adalah suci dan mendapat berkah dari Tuhan, pemutusan benang lawe atau janur yang dilingkarkan di perut calon ibu, dilakukan oleh calon ayah dengan maksud agar bayi yang dikandung akan lahir dengan mudah, calon ibu duduk di atas tumpukan baju dan kain yang tadi habis digunakan, upacara mecah kelapa, kelapa gading yang tadi dibawa ke kamar, kembali digendong oleh calon nenek untuk dibawa keluar dan diletakkan dalam posisi terbalik (gambar tidak terlihat) untuk dipecah, kelapa gadingnya berjumlah 2 dan masing masing digambari tokoh Wayang Kamajaya dan Kamaratih dan prosesi yang terakhir yaitu dodol rujak.

Hukum Islam pelaksanaan selamatan kehamilan (pitonan) dalam adat jawa masyarakat di dukuh Pacingkerep Ngandul Sumber lawang Sragen. Bahwa dalam tradisi selamatan kehamilan dapat saja dilakukan yang penting masyarakat tidak mengimani simbol-simbol yang terkait di dalam upacara selamatan kehamilan tersebut. Selamatan kehamilan juga merupakan perwujudan rasa syukur kepada Allah SWT sehingga dengan adanya tingkeban ini masyarakat melakukan salah satu perwujudan rasa syukurnya serta bersedekah kepada orang-orang. 


\section{REFERENSI}

http://pangeranarti.blogspot.co.id/2014/11/pengertian-adat-istiadatlengkap.html, (Diakses pada tanggal 29 Juli 2016)

Arifin, M., Hubungan Timbal Balik Pendidikan Agama, Jakarta: Bulan Bintang, 1997.

Arikunto, Suharsimi, Prosedur Penelitian Suatu Pendekatan Praktik, Jakarta: Rineka Cipta, 1998.

Barmawi, Bakir Yusuf, Pembinaan Kehidupan Beragama Islam Pada Anak, Semarang: Dina Utama, 1993.

Devania, Selamatan Kehamilan, diakses dari laman https://rullytricahyono. wordpress.com/2014/08/24/ kehamilan-minggu-ke-15-syukuran-4bulanan/, (Diakses pada tanggal 26 Agustus 2016)

Geertz, Clifford, Abangan, Santri, Priyayi dalam Masyarakat Jawa, Jakarta : Pustaka Jaya, 1983.

Hadi, Sutrisno, Statistik 2, Yogyakarta: Andi Offset, 1994.

Ibnu, Pengertian anak, http://makalah-ibnu.blogspot.com/2011/05/polaasuh-dalam-perspektif-ajaran-Islam.html, (Diakses pada tanggal 1 Agustus 2016)

Maia, Pengertian Mitoni, http://www.lacasacomics.com/2014/12/doawalimatul-haml-ngapati-4-bulan-dan.html, Diakses pada tanggal 20 Desember 2015

Moleong, Lexy J, Metodologi Penelitian Kualitatif, Bandung: PT Remaja Rosdakarya, 2009.

Muslim, Imam, Shohih Muslim Juz II, Semarang: Toha Putra, tt.

Nadia, Amalan-amalan Wanita Hamil, diakses dari laman http://azalialearns. blogspot.co.id/2014/10/amalan-ibu-hamil-menurut-Islam.html, (Diakses pada tanggal 1 Agustus 2016)

Septi, Pengertian Analisis, diakses dari laman http://www.pengertianahli.com/2014/08/pengertian-analisis-apa-ituanalisis.html, (Diakses pada tanggal 28 Juli 2016)

Soekamto, Soejono, Pengantar Penelitian Hukum, Jakarta:UI Press,1986. 
Soenarjo, dkk, Al-Qur'an dan Terjemahnya, Jakarta: Proyek Pengadaan Kitab Suci Al-Qur'an, Departemen Agama Republik Indonesia, 2003.

Tafsir, Ahmad, Pendidikan Agama Dalam Keluarga, Bandung: PT Remaja Rosdakarya, 2000.

Wulan, Pengertian Kehamilan, http://www.kopi-ireng.com/2015/01/definisidan-pengertian-kehamilan.html, (Diakses pada tanggal 30 Juli 2016) 